\title{
Pengembangan Modul Berbasis Pemecahan Masalah Pada Materi Asam Basa di SMA N 5 Kota Jambi untuk Membangun Keterampilan Metakognisi Siswa
}

\section{The Development of Problem Based Learning Modules of Acid Base Materials in SMA N 5 Jambi in Developing Student Metacognitive Skills}

\author{
Pauline Dewi Triani*; Nazarudin; M. Rusdi \\ Program Pascasarjana, Magister Pendidikan Kimia, Universitas Jambi, Jambi-Indonesia \\ *Korespondensi: dwitirani93@gmail.com
}

\begin{abstract}
Abstrak: Penelitian ini dilatarbelakangi keberhasilan pengembangan modul yang dijadikan sebagai bahan belajar mandiri bagi siswa. Namun pengembangan modul yang telah dilakukan sebelumnya hanya menampilkan tugas berupa soal pilihan ganda dan essay. Pada penelitian ini telah mencoba menerapkan tipe-tipe tugas dalam bentuk masalah yang dapat dijadikan sarana untuk meningkatkan proses belajar siswa. Penelitian ini bertujuan untuk mengetahui pengembangan modul berbasis pemecahan masalah yang berdaya guna dan bermanfaat bagi siswa, mengetahui proses penggunaan modul berbasis pemecahan masalah dalam pembelajaran pada materi asam basa, dan dampak modul berbasis pemecahan masalah dalam meningkatkan keterampilan metakognisi siswa. Metode penelitian yang digunakan adalah penelitian pengembangan dengan menggunakan model pengembangan ADDIE yang terdiri dari analisis, desain, development (pengembangan), Implementasi, dan Evaluasi. Data hasil penelitian yang diperoleh dari setiap tahapan model pengembangan ADDIE berupa data kualitatif yang dideskripsikan. Data penelitian diperoleh dari validator ahli, siswa dan guru. Hasil pengembangan modul berbasis pemecahan masalah yang dilakukan pengembang kepada dua validator ahli menyatakan modul layak untuk diujicobakan. Hasil dari ujicoba kelompok kecil modul mampu membangun keterampilan metakognisi siswa. Siswa mampu mengikuti setiap tahapan yang terdapat pada modul dengan baik.
\end{abstract}

Kata kunci: modul, masalah, metakognisi, pemecahan

\begin{abstract}
This research was motivated by the successful development of modules that serve as self-learning material for students, but the previous development of article the modules only show tasks in the form of multiple choice questions and essay. While there are so many types of tasks in the form of problems that can be used to improve student learning. This research goal was to understand how to develop module based on problem-based learning which are efficient and beneficial for the students, to analyse the application of problem-based learning modules on acid-base materials, and to understand the impact of problem-based learning modules to improve students' metacognition skills.This research used ADDIE development model consist of analysis, design, development, implementation, and evaluation. The data obtained from each stage of the ADDIE development model in the form of qualitative data were described. These were obtained from expert validators students and teachers. The problem based learning module developed by the researcher has been validated by two expert validators. The results from a small group trial showed that the students were able to follow each stage contained in modules well and was able to increase their metacognition skills using this module.
\end{abstract}

Keywords: modules, problem-based learning, metacognition

\section{PENDAHULUAN}

Materi asam basa merupakan salah satu materi yang bersifat abstrak, maka akan lebih mudah bagi siswa untuk melaksanakan proses pembelajaran dengan alat bantu salah satunya berupa modul. Modul merupakan bentuk bahan ajar berbasis cetakan yang dirancang untuk belajar mandiri oleh peserta pembelajaran karena modul dilengkapi dengan petunjuk untuk belajar sendiri tanpa kehadiran pengajar secara langsung (Asyhar, 2011).

Berdasarkan hasil penelitian yang dilakukan oleh beberapa pengembang terhadap pengembangan modul, seperti yang diungkapkan oleh Adhina (2012) yang menyatakan bahwa modul yang dikembangkan layak untuk dijadikan sumber belajar mandiri. Namun terdapat kekurangan pada penelitian ini yaitu, soal atau tugas yang disajikan pada modul kurang bervariasi, hal ini diperkuat oleh pernyataan pengembang yang menyarankan agar soal dapat dibuat seperti soal bercerita agar soal lebih mengena ke materi asam basa.

Selanjutnya pengembangan modul berbasis masalah yang dikembangkan oleh Nurul (2015) yang menyatakan modul 
berbasis masalah pada materi asam basa layak dan efektif dalam meningkatkan pemahaman konsep siswa pada materi asam basa. Namun masalah yang digunakan pengembang pada pengembangan modul ini tidak spesifik, padahal terdapat berbagai macam jenis masalah yang dapat disajikan.

Jonassen (2011) menjelaskan bahwa terdapat jenis-jenis masalah yang bervariasi, masalah tersebut dibedakan antara masalah well-structure dan ill-structure. Masalah wellstructure telah diketahui solusi yang dibutuhkan untuk menyelesaikan masalahnya berdasarkan oleh penerapan sejumlah konsep tetap, aturan-aturan, dan prinsip-prinsip. Masalah ill-structure memiliki beberapa solusi unsur yang tidak diketahui, hubungan yang tidak konsisten antara konsep, aturan, dan prinsip-prinsip.

Jenis masalah yang dimunculkan pada proses pembelajaran memiliki ciri yang khas dalam pembelajaran berbasis masalah. Contoh masalah well-structure dalam pembelajaran kimia yaitu masalah cerita, soal berupa pertanyaan yang bercerita mereaksikan suatu zat atau pembuatan larutan. Contoh ill-structure dalam pembelajran kimia yaitu masalah desain, untuk mengetahui persentase senyawa yang belum diketahui namun terdapat berat senyawa lain sebagai indikator untuk menyelesaikan masalah ini.

Tingkat kesulitan dalam menyelesaikan well-structure dan ill-stucture berbeda. Dengan perbedaan langkah penyelesaian maka akan berbeda pula karakter metakognisi siswa yang dihasilkan. Semakin baik karakter metakognisi siswa maka akan semakin baik pula siswa dalam menyelesaikan jenis-jenis masalah.

Metakognisi dalam pendidikan berarti menjelaskan cara berpikir siswa tentang bagaimana siswa belajar, hal ini melibatkan siswa untuk merefleksikan apa yang terjadi di kepala siswa untuk memecahkan masalah, cara apa yang dibutuhkan agar pengetahuan mereka terhubung ke pengetahuan lainnya, dan strategi bekerja apa yang terbaik bagi mereka sehingga mereka dapat menerapkan strategi untuk situasi lain di masa depan Veenmann (2006).

Jonassen (2011) membedakan dua karakteristik metakognisi, yaitu pengetahuan tentang kognisi dan regulasi mencakup pengetahuan tentang variabel tugas, strategi, pribadi. Artinya, pengetahuan metakognisi meliputi pengetahuan strategi (pengetahuan tentang strategi pembelajaran alternatif dan kapan harus menggunakannya) dan pengetahuan diri (pengetahuan tentang kemampuan seseorang dan kemampuan orang lain). Regulasi kognisi mencakup kemampuan untuk memonitor pemahaman seseorang dan mengendalikan kegiatan belajar seseorang.

Keterampilan metakognisi biasanya dikonseptualisasikan sebagai kesatuan yang saling kompeten untuk belajar dan berpikir, dan mencakup banyak keterampilan yang dibutuhkan untuk belajar aktif, berpikir kritis, penilaian reflektif, pemecahan masalah, dan pengambilan keputusan (Dawson, 2008).

Metakognisi sangat penting untuk keberhasilan belajar karena memungkinkan individu lebih baik dalam mengelola keterampilan kognitif mereka dan untuk menentukan kelemahan yang dapat diperbaiki dengan membangun keterampilan kognitif baru. Hal ini didukung melalui penelitian yang dilakukan oleh Danial (2010) yang menyatakan bahwa strategi PBL berpengaruh signifikan terhadap keterampilan metakognisi siswa serta penerapan strategi PBL mampu meningkatkan keterampilan metakognisi siswa. Serta penelitian yang dilakukan oleh Nurhayana (2012) mengenai hubungan keterampilan metakognisi dengan hasil belajar siswa. Hasil penelitian yang dilakukan menunjukkan hubungan yang signifikan antara keterampilan metakognisi dengan hasil belajar siswa.

Dalam penelitian ini, telah dikembangkan modul berbasis pemecahan masalahdan evaluasi proses penggunaan modul dan dampak modul berbasis pemecahan masalah dalam membangun keterampilan metakognisi.

\section{METODE}

Penelitian ini adalah penelitian pengembangan (Research and Development). Dalam penelitian pengembangan ini produk yang dihasilkan berupa modul pembelajaran kimia pada materi asam basa. Desain pengembangan dalam penelitian ini menggunakan model penggembangan ADDIE. Alasan menggunakan model ini karena produk pengembangan pembelajaran yang memerlukan langkah-langkah yang jelas.

Dalam penelitian ini, teknik pengumpulan data menggunakan observasi 
dan wawancara kepada validasi ahli, guru dan siswa.

Data kualitatif dalam penelitian ini berupa wawancara dan lembar observasi. Lembar observasi ini dianalisis jumlah kegiatan yang terlaksana dan tidak terlaksana. Tujuan digunakan lembar observasi ini adalah untuk mengevaluasi sejauh mana penggunaan modul dalam proses pembelajaran.

Miles dan Huberman (1984), mengemukakan bahwa aktivitas dalam analisis data kualitatif dilakukan secara interaktif dan berlangsung secara terus menerus sampai tuntas. Aktivitas dalam analisis data, yaitu: data reduction, data display, dan conclusion (Sugiyono, 2009).

\section{Data reduction}

Data yang diperoleh dari proses analisis, desain, mengembangkan, implementasi sampai pada tahap evaluasi akan direduksi. Mereduksi data berarti merangkum, memilih hal-hal yang pokok, memfokuskan pada halhal yang penting, dicari tema dan polanya dan membuang yang tidak perlu. Data yang telah direduksi akan memberikan gambaran yang jelas dan mempermudah peneliti untuk melakukan pengumpulan data selanjutnya, dan mencarinya bila diperlukan.

Reduksi data bisa dibantu dengan alat elektronik seperti: komputer, dengan memberikan kode pada aspek-aspek tertentu. Dengan reduksi, maka peneliti merangkum, mengambil data yang penting, membuat kategorisasi, serta menghilangkan data yang tidak dibutuhkan.

\section{Data display}

Setelah data direduksi, maka langkah berikutnya adalah mendisplaykan data. Data display dalam penelitian kualitatif bisa dilakukan dalam bentuk: uraian singkat, bagan, hubungan antar kategori, flowchart dan sebagainya. Miles dan Huberman dalam Sugiyono (2009) menyatakan: "the most frequent form of display data for qualitative research data in the pas has been narative tex" artinya: yang paling sering digunakan untuk menyajikan data dalam penelitian kualitatif dengan teks yang bersifat naratif. Selain dalam bentuk naratif, display data dapat juga berupa grafik, matriks, network (jejaring kerja).

\section{Conclusion drawing/verification}

Langkah ketiga adalah penarikan kesimpulan dan verifikasi. Kesimpulan awal yang dikemukakan masih bersifat sementara, dan akan berubah bila tidak ditemukan buktibukti yang kuat yang mendukung pada tahap pengumpulan data berikutnya. Namun bila kesimpulan memang telah didukung oleh bukti-bukti yang valid dan konsisten saat peneliti kembali ke lapangan mengumpulkan data, maka kesimpulan yang dikemukakan merupakan kesimpulan yang kredibel (dapat dipercaya). Kesimpulan dalam penelitian kualitatif yang diharapkan adalah merupakan temuan baru yang sebelumnya belum pernah ada. Temuan dapat berupa deskripsi atau gambaran suatu obyek yang sebelumnya masih belum jelas, sehingga setelah diteliti menjadi jelas.

\section{HASIL DAN PEMBAHASAN}

Tahap analisis merupakan tahap awal pengembangan ADDIE. Pada tahap ini sumber data yang diperoleh berasal dari salah satu guru kimia. Pada tahap observasi awal ini dilakukan untuk memperoleh data berupa karakteristik siswa, materi dan kurikulum yang digunakan, dan kebutuhan akan bahan ajar (Tabel 1).

Setelah melalui tahapan analisis selanjutnya tahap desain. Pada tahap ini menggunakan langkah-langkah pengembangan Dick and Carey. Sebelum modul dibuat langkah pertama yang dilakukan yaitu mengumpulkan informasi dan data yang telah terkumpul pada tahap sebelumnya yang dibuat dalam bentuk draf. Draf ini dijadikan landasan untuk membuat flowchart sebagai dasar pembuatan modul. Flowchart merupakan urutan-urutan langkah kerja suatu proses yang digambarkan dengan menggunakan simbol-simbol yang disusun secara sistematis Iswandy (2015).

Selanjutnya dari flowchart dibuat storyboard yang akhirnya bisa menjadi dasar untuk membuat modul. Storyboard merupakan uraian yang berisi visual dan audio penjelasan dari masing-masing alur dalam flowchat. Satu kolom dalam storyboard mewakili satu tampilan modul. Salain itu, pengumpulan referensi yang digunakan dalam menyusun dan mengembangkan materi dalam modul. Modul 
ini dibuat dengan menggunakan aplikasi Microsoft Office Publisher.

Tahap selanjutnya yaitu tahap pengembangan. Tahap pengembangan merupakan tahap penyusunan produk. Pada tahap ini pengembangan modul dilakukan sesuai dengan tahap perencanaan yang menghasilkan rancangan prototype. Rancangan prototype ini selanjutnya akan divalidasi oleh tim ahli berupa validasi desain pembelajaran dan validasi materi.

Hasil dari tahap pengembangan berupa saran-saran perbaikan modul yang diberikan oleh validator ahli. Hasil pada tahapan implementasi. Tahap implementasi merupakan tahap ujicoba kelompok kecil yang menggunakan hasil berupa lembar observasi. Lembar observasi digunakan untuk melihat aktivitas siswa selama proses pembelajaran menggunakan modul berbasis pemecahan masalah. Hasil observasi selama proses pembelajaran berlangsung.disajikan dalam Tabel 2.

Tabel 1. Hasil observasi pendahuluan

\begin{tabular}{|c|c|c|}
\hline No & Kategori & Hasil Wawancara \\
\hline 1. & $\begin{array}{l}\text { Karakterist } \\
\text { ik siswa }\end{array}$ & $\begin{array}{l}\text { Siswa memiliki kemampuan } \\
\text { yang heterogen }\end{array}$ \\
\hline 2. & & Minat siswa berbeda-beda \\
\hline 3. & Materi & $\begin{array}{l}\text { Siswa kurang tertarik akan } \\
\text { materi bersifat hitung-hitungan }\end{array}$ \\
\hline 4. & $\begin{array}{l}\text { Ketersedia } \\
\text { an bahan } \\
\text { ajar }\end{array}$ & $\begin{array}{l}\text { Siswa menggunakan buku paket, } \\
\text { LKS, dan internet }\end{array}$ \\
\hline 5. & $\begin{array}{l}\text { Keterlaksa } \\
\text { naan tugas }\end{array}$ & $\begin{array}{l}\text { Siswa mengerjakan tugas yang } \\
\text { diberikan guru }\end{array}$ \\
\hline 6. & Kurikulum & $\begin{array}{l}\text { Kurikulum yang digunakan } \\
\text { disekolah kurikulum } 2013\end{array}$ \\
\hline 7. & $\begin{array}{l}\text { Pengetahu } \\
\text { an materi } \\
\text { asam basa }\end{array}$ & $\begin{array}{l}\text { Siswa telah mengetahui materi } \\
\text { asam basa }\end{array}$ \\
\hline 8. & $\begin{array}{l}\text { Kendala } \\
\text { didalam } \\
\text { belajar }\end{array}$ & $\begin{array}{l}\text { Kendala yang dialami ketika } \\
\text { mengajar waktu yang terkadang } \\
\text { kurang }\end{array}$ \\
\hline 9. & $\begin{array}{l}\text { Bentuk } \\
\text { tugas }\end{array}$ & $\begin{array}{l}\text { Bentuk tugas berupa fortofolio, } \\
\text { soal berupa pilihan ganda dan } \\
\text { essay }\end{array}$ \\
\hline 10. & $\begin{array}{l}\text { Kebutuhan } \\
\text { akan } \\
\text { bahan ajar }\end{array}$ & $\begin{array}{l}\text { Guru belum pernah } \\
\text { mengembangkan bahan ajar } \\
\text { Bahan ajar yang diharapkan } \\
\text { guru, bahan ajar yang bisa } \\
\text { menuntun siswa belajar mandiri } \\
\text { dan melatih kemampuan } \\
\text { berpikir siswa. }\end{array}$ \\
\hline
\end{tabular}

Tahap terakhir yaitu tahap evaluasi. Tahap evaluasi merupakan tahap terakhir pada proses pengembangan ADDIE. Data yang diperoleh pada tahap evaluasi ini berupa data wawancara 6 orang siswa dan 1 orang guru untuk mengetahui respon siswa dan guru terhadap produk yang telah digunakan (Tabel $3)$.

Tabel 2. Hail observasi ujicoba kelompok kecil

\begin{tabular}{cll}
\hline No & Indikator Observasi & \multicolumn{1}{c}{ Hasil Observasi } \\
\hline 1. & Petunjuk & Sebelum \\
& penggunaan modul & melaksanakan proses \\
& memudahkan siswa & pembelajaran, guru \\
& dalam mempelajari & menjelaskan cara \\
materi pada modul. & penggunaan modul & kepada siswa melalui \\
& petunjuk modul yang \\
& disajikan pada modul. \\
& Sehingga petunjuk \\
& modul memudahkan \\
& siswa menuntun \\
& mempelajari modul. \\
& Dengan bahasa yang \\
& mudah dipahami siswa \\
& mempelajari materi \\
& asam basa dengan \\
& mudah.
\end{tabular}

2. Penjelasan pada modul mudah dipahami siswa.

Dengan adanya langkah-langkah pada modul, siswa mampu mempelajari materi asam basa yang disajikan didalam modul.

3. Langkah-langkah pada modul memudahkan siswa menggunakan modul.

4. Kesulitan atau kendala yang dialami siswa ketika menggunakan modul.

Kendala yang dialami siswa didalam menggunakan modul tidak terlalu terlihat, karena bila siswa mengalami kesulitan siswa bertanya kepada guru dan guru segera memberikan penjelasan terhadap pertanyaan yang diajukan oleh siswa.

Tugas yang diberikan oleh guru tersaji didalam modul, untuk mengetahui syarat akan tugas yang diberikan siswa dapat membacanya pada profil modul.

5. Modul membantu siswa mengetahui syarat tugas yang diberikan guru.

\section{Untuk mengetahui sampai dimana pengetahuan siswa, siswa dapat mengecek kemampuannya melalui Ayo Cek}

6. Siswa mengetahui kemampuannya dalam menguasai materi. mana kemampuan
Pemahamanmu". Pada bagian ini siswa dapat mengukur sampai pemahaman siswa terhadap materi asam basa. 
Tabel 3.Hasil wawancara siswa

\begin{tabular}{|c|c|c|}
\hline No & Kategori & Hasil wawancara \\
\hline 1. & $\begin{array}{l}\text { Kemudahan } \\
\text { menggunakan } \\
\text { modul }\end{array}$ & $\begin{array}{l}\text { Petunjuk penggunaan } \\
\text { modul memudahkan siswa } \\
\text { didalam mempelajari } \\
\text { modul }\end{array}$ \\
\hline 2. & $\begin{array}{l}\text { Kemudahan } \\
\text { memahami isi } \\
\text { modul }\end{array}$ & $\begin{array}{l}\text { Penjelasan pada modul } \\
\text { menggunakan bahasa yang } \\
\text { sederhana dan mudah } \\
\text { dipahami siswa }\end{array}$ \\
\hline 3. & $\begin{array}{l}\text { Kemudahan } \\
\text { menggunakan } \\
\text { modul }\end{array}$ & $\begin{array}{l}\text { Langkah penggunaan } \\
\text { modul yang disajikan } \\
\text { memudahkan siswa dalam } \\
\text { menggunakan modul }\end{array}$ \\
\hline 4. & $\begin{array}{l}\text { Kendala saat } \\
\text { mempelajari } \\
\text { modul }\end{array}$ & $\begin{array}{l}\text { Tidak terdapat kesulitan } \\
\text { didalam menggunakan } \\
\text { modul }\end{array}$ \\
\hline 5. & $\begin{array}{l}\text { Pemantauan } \\
\text { pengetahuan } \\
\text { awal }\end{array}$ & $\begin{array}{l}\text { Siswa dapat memantau } \\
\text { pengetahuan awal melalui } \\
\text { "gali pemahaman awalmu" }\end{array}$ \\
\hline 6. & $\begin{array}{l}\text { Modul sebagai } \\
\text { alat pantau } \\
\text { pembelajaran }\end{array}$ & $\begin{array}{l}\text { Modul mampu mengontrol } \\
\text { pemahaman siswa }\end{array}$ \\
\hline 7. & $\begin{array}{l}\text { Kesesuaian tugas } \\
\text { dengan materi }\end{array}$ & $\begin{array}{l}\text { Pertanyaan sesuai dengan } \\
\text { materi asam basa pada } \\
\text { modul }\end{array}$ \\
\hline 8. & $\begin{array}{l}\text { Sumber } \\
\text { informasi lain }\end{array}$ & $\begin{array}{l}\text { Siswa dapat menemukan } \\
\text { informasi dari berbagai } \\
\text { sumber }\end{array}$ \\
\hline 9. & $\begin{array}{l}\text { Hubungan modul } \\
\text { dengan } \\
\text { kehidupan } \\
\text { sehari-hari }\end{array}$ & $\begin{array}{l}\text { Isi modul dapat } \\
\text { mengaitkan dengan } \\
\text { kehidupan sehari-hari }\end{array}$ \\
\hline 10 & $\begin{array}{l}\text { Keterampilan } \\
\text { merangkum }\end{array}$ & $\begin{array}{l}\text { Siswa dapat merangkum } \\
\text { informasi setelah } \\
\text { melakukan proses } \\
\text { pembelajaran }\end{array}$ \\
\hline
\end{tabular}

Setelah melaksanakan uji coba kelompok kecil terhadap enam orang siswa yang dengan tingkat kemampuan yang berbeda-beda. Peneliti melakukan wawancara terhadap keenam siswa. Pertanyaan yang diajukan kepada siswa sekitar 10 pertanyaan. Berikut pembahasannya.

Pembahasan pertama mengenai kemudahan penggunaan modul. Dari keenam siswa yang ditanyakan dapat disimpulkan bahwa petunjuk penggunaan modul memudahkan siswa di dalam mempelajari modul. Berikut kutipan wawancara terhadap salah satu siswa.

"Ya, mudah dipahami karena di modul terdapat petunjuk dan peta konsep", namun terdapat satu siswa yang memiliki pendapat yang berbeda, yaitu siswa keenam. Berikut kutipan wawancara siswa keenam. 'Tidak, karena pada modul terdapat peta konsep tetapi tidak dijelaskan secara rinci."

Jawaban atas pertanyaan yang diajukan kepada siswa tidak sesuai. Peneliti menanyakan mengenai petunjuk penggunaan modul, tetapi siswa membahas peta konsep. Petunjuk penggunaan modul telah dijelaskan oleh guru sebelum proses pembelajaran, dan siswa juga dapat membaca sendiri petunjuk penggunaan modul.

Pembahasan kedua mengenai kemudahan memahami isi modul. Kesimpulan dari enam orang siswa menjawab bahwa penjelasan pada modul menggunakan bahasa yang sederhana dan mudah dipahami siswa. Berikut kutipan dari salah satu siswa. 'Mudah, karena didalam modul ini sudah dijelaskan materi asam basa secara jelas dan rinci”

Berikut kutipan percakapan jawaban dari siswa lainnya senada dengan jawaban siswa pertama. "Mudah karena menggunakan bahasa yang jelas dan tidak terlalu tinggi", namun terdapat satu pendapat berbeda yaitu dari siswa keenam, yang menyatakan bahwa langkah pada penggunaan modul tidak dapat memudahkan siswa tersebut didalam menggunakan modul. Berikut kutipan jawaban wawancara siswa keenam. 'Tidak, karena peta konsep tidak dijelaskan secara rinci”.

Menurut Asyhar (2011) peta konsep atau peta informasi memperlihatkan kaitan antar topik-topik dalam modul. Peta konsep yang disajikan didalam modul dibuat dalam bentuk diagram isi modul. Peta konsep juga dibuat berdasarkan kata-kata kunci materi yang tersaji didalam modul. Sehingga seharusnya peta konsep yang telah tersaji didalam modul sudah cukup memudahkan siswa menggunakan modul secara garis besar.

Pembahasan ketiga mengenai langkahlangkah pada modul memudahkan siswa menggunakan modul. Dengan adanya langkah-langkah pada modul, siswa mampu mempelajari materi asam basa yang disajikan di dalam modul.

Pembahasan keempat mengenai kendala saat menggunakan modul. Menurut kelima siswa pada saat menggunakan modul, tidak terdapat kendala yang berarti. Namun menurut salah satu siswa penjelasan mengenai asam basa kurang. Hal ini tidak sesuai dengan yang tersaji pada modul. Pada modul telah dijelaskan cara rinci mengenai penjelasan materi asam basa. Hal ini terbukti karena tidak terdapat koreksi dari validator materi mengenai penjelasan asam basa yang kurang lengkap. Siswa yang lain dan guru juga tidak berkomentar akan kurangnya penjelasan materi asam basa. 
Pembahasan kelima mengenai pemantauan pemahaman awal. Kesimpulan yang diperoleh dari keenam siswa yaitu siswa dapat memantau pengetahuan awal melalui gali pemahaman awalmu. Berikut salah satu kutipan siswa, 'Ya, awalnya saya tidak mengetahui bagaimana praktikum dengan menggunakan lakmus sekarang sudah dapat mengetahui. Dan juga didalam modul terdapat gali pemahaman awalmu". Pembahasan keeenam mengenai modul sebagai alat pantau siswa. Kesimpulan jawaban dari keenam siswa yaitu modul mampu mengontrol pemahaman siswa.

Pembahasan ketujuh membahas kesesuaian tugas dengan materi. Kesimpulan jawaban dari keenam siswa yaitu pertanyaan sesuai dengan materi asam basa pada modul.

Pembahasan kedelapan menanyakan siswa dapat mengumpulkan informasi dari sumber lain. Siswa menjelaskan bahwa siswa mencari informasi melalui buku paket sekolah, LKS, dan internet.

Pembahasan kesembilan menanyakan hubungan modul dengan kehidupan seharihari. Kesimpulan dari jawaban keenam siswa isi modul dapat dikaitkan dengan kehidupan sehari-hari.

Pembahasan terakhir mengenai ketemapilan merangkum, keenam siswa menjawab bahwa mereka mampu merangkum materi yang terdapat pada modul melalui kolom rangkuman.

Informasi terakhir diperoleh dari guru mengenai respon guru terhadap modul berbasis pemecahan masalah pada materi asam basa. Adapun kategori pertanyaan diperoleh dari kajian pustaka yang terdiri dari: modul, metakognisi, dan pemecahan masalah.

Adapun pembahasannya sebagai berikut. Pertama kategori modul sebagai alat bantu guru. Peneliti menanyakan mengenai modul mendukung peran guru sebagai fasilitator. Modul dibuat dengan bahasa yang mudah dipahami dan dibantu dengan petunjuk penggunaan sehingga dapat membantu untuk mengajar. Pembahasan kedua kategori aktivitas belajar mengenai modul membantu guru dalam pembelajaran untuk membantu aktivitas siswa. Di dalam modul terdapat langkah-langkah kerja yang harus dilalui siswa di dalam setiap subbabnya sehingga dapat dijadikan alat untuk membantu aktivitas siswa.

\begin{tabular}{|c|c|c|}
\hline No & Kategori & Hasil Wawancara \\
\hline 1 & $\begin{array}{l}\text { Modul alat } \\
\text { bantu guru }\end{array}$ & $\begin{array}{l}\text { Tanggapan guru sangat } \\
\text { baik terhadap peran } \\
\text { modul sebagai alat bantu } \\
\text { guru }\end{array}$ \\
\hline 2. & Aktivitas belajar & $\begin{array}{l}\text { Dengan adanya langkah- } \\
\text { langkah didalam } \\
\text { menggunakan modul } \\
\text { dapat membantu guru } \\
\text { dalam memantau aktivitas } \\
\text { belajar siswa }\end{array}$ \\
\hline 3 . & Materi & $\begin{array}{l}\text { Manurut guru siswa dapat } \\
\text { terbantu dengan adanya } \\
\text { modul asam basa }\end{array}$ \\
\hline 4. & $\begin{array}{l}\text { Kemudahan } \\
\text { memahami isi } \\
\text { modul }\end{array}$ & $\begin{array}{l}\text { Penggunaan isi modul } \\
\text { mudah dipahami }\end{array}$ \\
\hline 5 . & $\begin{array}{l}\text { Modul sebagai } \\
\text { alat kontrol } \\
\text { pembelajaran }\end{array}$ & $\begin{array}{l}\text { Modul dapat membantu } \\
\text { guru didalam mengontrol } \\
\text { pengetahuan siswa }\end{array}$ \\
\hline 6. & $\begin{array}{l}\text { Melatih } \\
\text { kemampuan } \\
\text { berpikir }\end{array}$ & $\begin{array}{l}\text { Modul dijadikan sarana } \\
\text { untuk siswa melatih } \\
\text { kemampuan berpikir }\end{array}$ \\
\hline 7. & Tugas & $\begin{array}{l}\text { Siswa belajar secara } \\
\text { kelompok melalui modul }\end{array}$ \\
\hline 8. & $\begin{array}{l}\text { Kemampuan } \\
\text { merangkum }\end{array}$ & $\begin{array}{l}\text { Siswa dapat merangkum } \\
\text { informasi yang didapat } \\
\text { melalui modul }\end{array}$ \\
\hline 9. & $\begin{array}{l}\text { Model yang } \\
\text { digunakan pada } \\
\text { modul }\end{array}$ & $\begin{array}{l}\text { Model mengikuti langkah } \\
\text { PBL }\end{array}$ \\
\hline 10 & Fungsi Modul & $\begin{array}{l}\text { Modul sebagai alat bantu } \\
\text { mandiri }\end{array}$ \\
\hline 11. & Fungsi Modul & $\begin{array}{l}\text { Siswa dapat mengetahui } \\
\text { kemampuan diri melalui } \\
\text { modul }\end{array}$ \\
\hline
\end{tabular}

Pembahasan ketiga kategori materi mengenai modul dapat membantu siswa memahami materi. Pembahasan keempat kategori kemudahan memahami isi modul, siswa secara keseluruhan dapat memahami modul karena menggunakan bahasa yang sederhana sesuai dengan siswa.

Pembahasan kelima kategori modul sebagai alat kontrol pembelajaran. Modul membantu guru dalam mengontrol pemahaman siswa. Pada modul terdapat "gali pengetahuan awalmu" untuk mengetahui pengetahuan awal siswa dan "rangkumlah" untuk mengetahui pengetahuan siswa setelah menggunakan modul. Pembahasan keenam katergori modul melatih kemampuan berpikir. Modul membantu guru meningkatkan kemampuan berpikir siswa. Di dalam modul terdapat tugas-tugas yang membantu siswa untuk harus menganalisis tugas yang diberikan. Hal itu dapat membantu siswa belajar lebih mendalam lagi. 
Pembahasan ketujuh kategori mengenai tugas mengenai modul membantu guru menuntun siswa untuk belajar dalam kelompok. Di dalam modul terdapat tugas yang mengharuskan siswa bekerja dalam kelompok. Pembahasan kedelapan kategori mengenai kemampuan merangkum. Modul membantu guru menuntun siswa merangkum informasi yang telah dipelajari. Pada modul telah terdapat ruang bagi siswa merangkum materi yang telah dipelajari. Pembahasan kesembilan kategori penggunaan model yang ada pada modul. Model yang digunakan mengikuti langkah pada model PBL seperti: orientasi, organisasi, investigasi, mengembangkan, analisis, dan evaluasi. Pembahasan terakhir mengenai fungsi modul. Modul yang dikembangkan peneliti membantu siswa belajar mandiri dan modul membantu siswa didalam memahami kemampuan dirinya melalui kolom penilaian mandiri.

\section{KESIMPULAN}

Kesimpulan penelitian ini sebagai berikut:

1. Proses pengembangan pada pengembangan modul berbasis pemecahan masalah ini menggunakan model pengembangan ADDIE. Pada proses pengembangan ini diperoleh beberapa perbaikan oleh validator ahli yaitu validator desain pembelajaran dan materi.

2. Pada proses penggunaan modul siswa mampu mengikuti setiap tahapan yang tersaji pada modul secara runut dengan dibimbing oleh guru.

3. Dampak modul bagi proses pembelajaran yang dilakukan siswa yaitu siswa mampu mengikuti setiap tahapan kemampuan metakognisi yang tersaji pada modul dengan baik.

\section{DAFTAR PUSTAKA}

Adhina, A.N. (2012). Pengembangan Modul Pengayaan Materi Asam-Basa dan Kesetimbangan Kelarutan Berbasis Motivasi dan Aplikasi Untuk Peserta Didik Semester II Kelas XI IPA SMA/MA.
Universitas Negeri Yogyakarta, Fakultas Matematika dan Ilmu Pengetahuan Alam. Asyhar, R. (2011). Kreatif Mengembangkan Media Pembelajaran. Jakarta: GP Press. Atwi, M.S. (2015). Desain Instruksional Modern Panduan Para Pengajar dan Inovator Pendidikan. Jakarta: Erlangga

Danial, M. (2010). Pengaruh Strategi PBL Terhadap Keterampilan Metakognisi dan Respon Siswa. Jurnal Chemica, 11:1-10.

Dawson, T.F.K. (2008). Metacognition and Learning Adulthood. Contemporary Education Psychology.

Iswandy, E. (2015). Sistem Penunjang Keputusan Untuk Menentukan Penerimaan Dana Santunan Sosial Anak Nagari dan Penyalurannya Bagi Mahasiswa dan Pelajar Kurang Mampu Di Kenagarian Barung-Barung Balantai Timur. TEKNOIF.

Jonassen, D. (2011). Learning to Solve Problem A Handbook for Designing Problem-Solving Learning Environment

Nurhayana, E. (2012). Hubungan Keterampilan Metakognisi Dengan Hasil Belajar Siswa Pada Materi Reaksi Reduksi Oksidasi (Redoks) Kelas X-I SMA Negeri 3 Sidoarjo. Unesa Journal of Chemical Education, 1.

Nurul, H.K. (2015). Pengembangan Modul Kimia Berbasis Masalah Padsa Materi Asam Basa. Chemistry in Edducation.

Miles, M.B., \& Huberman, A.M. (1984) Qualitative Data Analysis: a Source Book or New Methods. Beverly Hills: Sage Publication

Schraw, G., Crippen, K.L., \& Hartley, K. (2006). Promoting self-regulation in science education : Metacognition as part of a broader prespective on learning. Research in Science Education.

Sugiyono. (2009). Metode Penelitian Kuantitatif Kualitatif dan $R \& D$. Bandung: Alfabeta.

Veenmann, M.V.J., Bernadette, H.A.M., \& Afflerbach, P. (2006). Metacognition and Learning: Conceptual and methodological consideration. 